\title{
GAMES PEOPLE PLAY: METATHEATRE AS PERFORMANCE CRITICISM IN PLAUTUS' CASINA
}

\author{
Bronwyn Williams
}

Casina is one of Plautus' most metatheatrical comedies. ${ }^{1}$ Self-reflexive role-play, plays within plays, explicit references to theatrical context or convention are usual in Plautine drama. In Casina they constitute much or most of the dramatic action. During the prologue the audience is encouraged to sit back and enjoy the games (23ff.); whereas by Act 5 it is the play's women who have come out 'to watch the wedding games out here on the street' (ludos visere huc in viam nuptialis, 856). The stage-set, which the audience accepts implicitly as 'a street', has been turned back into a stage-set. ${ }^{2}$ The women converse like a regular audience: Myrrhina in particular has 'never laughed so much in one day' (numquam ... ullo die risi adaeque, 857) and thinks theirs the equal of any play ever written (860f.). Moreover, when Olympio enters, he acknowledges the 'real' audience with his narrative of events inside Alcesimus' house, but seems oblivious of the on-stage audience-which is dependent for its early information concerning Olympio's wedding night on his relations to the former, real audience. What is involved here is a complete reversal of the conventions of illusionistic theatre, in which the audience finds out about off-stage action from the conversation of characters inside the drama. Pardalisca's interruption restores the conventional order: the remainder of Olympio's narrative is told, ostensibly, to her; the audience is returned to the condition of unseen eavesdroppers.

This is the play's climactic act; but Casina's metatheatrical design is evident throughout. Casina's metatheatrical content constitutes a consistent, systematic and holistic approach to the dramatic action. In this essay, I intend first to analyse Casina's metatheatrical design and content.

Secondly, I want to consider Casina's concern with human relationships, with the conscious or subconscious role-play and gamesmanship in which human beings participate and by which they attempt to exercise control over one another and over circumstance. I will contend that Plautus uses metatheatrical strategies in Casina partly to elucidate the politics of these relationships.

Thirdly, my critical method will be performance criticism. I intend to treat the text as a script devised with performance and an audience in mind. I will suggest possible options for staging some scenes and delivering certain lines. I assume that the way in which these are staged or delivered is relevant to the experience enjoyed by the audience, and therefore to the interpretation formed by that member of the audience who is also a critic. 


\section{BRONWYN WILLIAMS}

My critical focus includes actors, audience, performance, dynamics-and what these contribute to the play's meaning.

\section{Programme Notes}

Casina's prologue functions programmatically in several respects. ${ }^{3}$ First it establishes theatrical context and signals metatheatrical context. The theatrical flourish and mock grandeur of the initial greeting (1-4)-and of the closing benediction (87-88)-are self-consciously theatrical and consonant with the epic self-imaging of Lysidamus and mock-tragic pose of Pardalisca. Fides, 'Fidelity' is established as a central idea (if not ideal), appropriately, ${ }^{4}$ since the play's principal character is a philandering husbandand his wife, in turn, deals with him by breaking faith with the decision imposed by the lots, and by instituting a sequence of deceptions against him. (Not surprisingly, when Cleostrata agrees to forgive Lysidamus his indiscretions, his first question is 'can I trust your fidelity?' [tuaen fidei credo?, 1007].) Next (assuming that lines 5-22 only are post-Plautine) ${ }^{5}$ there follows a series of references to the present context, the theatrical games (ludi, ludus, 25; ludis, 27; ludos, 28), which anticipate the explicit references to Cleostrata's plots as theatrical games (ludi, 761; ludos, 856) in Acts 4 and 5. Line 25-

ludi sunt, ludus datus est argentariis

The games are on, the game is on for the bankers too

—establishes the double sense of ludus, 'a trick'/'a play', which is taken up repeatedly later on. ${ }^{6}$ In Act 3 Pardalisca is sent out both to play a trick on Lysidamus, and to perform a play for him (ludere, 688). Lysidamus is played up to and played false (ludificatus, 558) by Cleostrata. Alcesimus complains that Lysidamus has played him and his wife for fools (ludificatust, 592) -or that Lysidamus has put them in a play. (Alcesimus' house is to be the stage for Lysidamus' country scenario [485].) Hence lines 14 and 23-28 provide the audience with clues about Casina's theatrical and metatheatrical substance.

Secondly, the prologue is concerned with the relationship between Casina and its New Comic history. Ostensibly the play is a straight translation (31-34):

Clerumenoe vocatur haec comoedia graece, latine Sortientes. Diphilus hanc graece scripsit, postid rursum denuo latine Plautus cum latranti nomine. 


\section{GAMES PEOPLE PLAY}

This play is called in Greek Clerumenoe, The Lot Drawers-in Latin Sortientes. Diphilus wrote it in Greek; afterwards Plautus with the barking name wrote it again afresh in Latin.

However, in the course of the prologue Plautus rids the play of scenes and characters central to the Greek original (as Plautus depicts or [re]creates it). ${ }^{7}$ The slave who discovered the baby Casina is sick in bed (37f.). As a result (although this is apparent only in retrospect) the play has to be staged without the recognition scene, to which he is essential. (If he were available, still the scene could not take place, as Casina herself never makes an appearance.) Euthynicus is abroad, and won't be coming back, at least not in this comedy (64ff.). Euthynicus' mother will be defending his interests and her own (63). At this point the audience might reconsider and distinguish a significant difference grammatically between the Greek and Latin titles. Both are nominative plural participles, but whereas the Greek is masculine specifically, 'men drawing lots', the Latin is masculine or feminine. The Greek title connotes primarily masculine activity. In Plautus' version a woman, Cleostrata, draws the lot-a point is made of it by Lysidamus (393ff.). And Casina is less about male rivalry (although it is about male rivalry too) than about male/female, particularly marital relations.

Clerumenoe's plot is relegated largely to Sortientes' prologue, and summarised in a fashion calculated to point up its generic conventionality. Consider, for example, lines 39ff.:

is servos, sed abhinc annos factum est sedecim quom conspicatust primulo crepusculo puellam exponi.

This slave, but it happened sixteen years ago when he saw the girl being abandoned in the early twilight.

The colloquial manner, the fact that what the slave saw is described in a subordinate clause, contribute to the sense that what is being described is entirely normal, and that slaves are always witnessing the abandonment of baby girls, particularly at twilight. Generically, it is normal and they do so witness. The slave's scene is dealt with as a series of momentsapproach, appeal and success, firstly in obtaining custody of the girl, and secondly in persuading his mistress to take her in. It is expressed, with minimal padding, through a series of indicatives: he approaches (adit), entreats (orat), persuades (exorat), carries off (aufert), carried away (detulit), gives (dat), entreats (orat); his mistress did as she was asked (fecit), and educated Casina (educavit). Implicit is 'you know the routine'. ${ }^{8}$

The remaining background to the plot shifts temporally from the distant to the immediate past. Father and son have already been introduced to the 


\section{BRONWYN WILLIAMS}

audience briefly (35f.); now they are reintroduced in conflict. Plautus' stamp is on the military language which is used here to define an amorous campaign: both 'make ready their legions' (legiones parat), and appoint seconds (adlegavit). Euthynicus appoints his armour-bearer (armigerum); Lysidamus hopes to arrange 'night quarters' (excubias) for himself without his wife's knowledge. The audience is given a run-down of campaign tactics, move by move: 'the father appointed' (pater adlegavit) - 'the son appointed' (filius ... adlegavit); one 'hopes' (sperat) - the other 'knows' (scit); 'the wife perceived' her husband's intentions (uxor sensit)-'he perceived' (ille ... sensit) those of his son. Lysidamus removes Euthynicus from the action (sends him off on a mission, in fact [ablegavit, 62]) Cleostrata takes his place.

With this last manoeuvre the focus of the plot description shifts from father and son to husband and wife. The audience is signalled that this is not a revival but a rewriting of Diphilus' play, with new emphasis. The issue will not be how son deals with father as rival, but how wife deals with husband as cheat. A conventional happy conclusion is anticipated summarily in the final section of the prologue (79ff.)-the girl will turn out to be modest, free-born, a native Athenian and a virgin. The conclusion of Lysidamus' and Cleostrata's marital strife is left open. Diphilus' Clerumenoe is brought before the audience by way of background to Plautus' Sortientes. The stage is set for an original, distinctly Plautine treatment of subject and character. ${ }^{9}$

Plautus' position in relation to his own play, and the situation of the playwright in general are the prologue's third concern. Euthynicus' absence from the play is explained metatheatrically. Theatrically, the audience would have been satisfied with the information that Lysidamus has sent his son away on business (cf. 60ff.); but the prologue adds (64-66):

\section{is, ne expectetis, hodie in hac comoedia \\ in urbem non redibit: Plautus noluit; \\ pontem interrupit, qui erat ei in itinere.}

Don't expect him-he won't return to the city today in this comedy: Plautus woudn't have it; he broke down a bridge on the way home for that one.

Instantly, a three-dimensional image is evoked of the playwright-out sawing down the bridge, hiding in wait for the thwarted Euthynicus. It highlights the status of the play as product of the playwright's imagination, and it refers all the plots of Lysidamus and Cleostrata to the arch-plotter Plautus. (Plautus here is like Palaestrio in Miles Gloriosus, when he remarks to the audience, of Philocomasium's 'dream', 'she's describing Palaestrio's dream' [Palaestrionis somnium narratur, Miles 386].) Moreover it exposes a theatrical convention-the convention of explaining away 


\section{GAMES PEOPLE PLAY}

absences. The script-writers for modern television series and soap opera know all about this one. In the Australian soap Neighbours Scott and Charlene went to Queensland, while the actors who portrayed them embarked on careers as recording artists. In later episodes of the American series The Virginian the title character was regularly absent 'on a cattle drive'. The playwright has to respond to constraints imposed by the real world (such as the unavailability of certain actors for a particular performance) or, if he makes a voluntary decision to remove a character, to the demands of internal logic (by which characters can't just disappear). Plautus draws attention to the artificiality of the world of the play, and the semi-autonomy of its creator, who can break down fictional bridges at will, and who may be constrained to break them down, in accordance with theatrical convention and audience expectation.

The fourth point made by the prologue is that the world of the play and the world of the audience are disjunct. The playwright has complete control over the morals of Casina, but none whatsoever over those of the actor playing the role (81-86):

ea invenietur et pudica et libera, ingenua Atheniensis, neque quicquam stupri faciet profecto in hac quidem comoedia. mox hercle vero, post transactam fabulam, argentum si quis dederit, ut ego suspicor, ultro ibit nuptum, non manebit auspices.

She will be discovered to be both modest and free-born, a native Athenian, and guilty of no unchastity to be sure in this comedy at any rate. Presently indeed by god, when the play is over, if someone pays out money, it's my opinion she'll marry anyone, and not wait for the ceremony.

Of course retrospectively there is another level to this metatheatrical qualification, which is that Casina never appears, and so there is no actor in the case. He is less real even than the character he never portrays. ${ }^{10}$ The slave wedding sequence, by its very recourse to real-world precedents, reemphasises the illusory nature of the stage-world. ${ }^{11}$ Following the metatheatrical manoeuvre which rids the play of the Young Man in Love, the prologue ventures $(67 f$.$) :$

sunt hic inter se quos nunc credo dicere:

'quaeso hercle, quid istuc est? serviles nuptiae?'

There are those among you who I think are saying among themselves: 'I ask you by god, what's this? Slave weddings?' 


\section{BRONWYN WILLIAMS}

The first line and a half turns out to be a false lead. If the audience is saying 'what's this', then it is more probably a response to the metatheatrical gameplay just executed. The prologue is toying with the audience in its explanation of some completely different feature of the play. The absurdity of the ensuing discourse is just this: that most of the circumstances of New Comedy belong in a fictive world, which the audience tacitly agrees to accept when it enters the theatre, as rules of the game. If the playwright wishes to include slave weddings in his fictive world, then that is a world which he controls, and they will suspend disbelief on this matter also. ${ }^{12}$ The playwright controls the world of the play.

Casina's prologue signals the theatrical and metatheatrical tendencies of the play as a whole; its conventionality and originality; its focus on the playwright both as controlling figure in the world of the play and as artist constrained by the world outside the play; its focus on the disjuncture between the world of the play and the world of the audience. It reveals little about the substance, but a great deal about the style of the ensuing drama.

\section{War Games}

Acts 1 and 2 take up the issues raised by the prologue. Act 1 is a dramatic inset. Olympio and Chalinus enter, interact and exit, and the play starts over. The scene makes no contribution towards the advancement of the play's action. However, it is important for two reasons. Firstly the slapstick of the slaves both relieves and highlights the undercurrent of seriousness beneath the comedy of Act $2 .{ }^{13}$ Cleostrata's verbal assaults on Lysidamus are more disturbing inherently than Chalinus' abuses of Olympio, inasmuch as the former are semi-realistic, while the latter are pure theatrics. Cleostrata is placed in a realistic situation, a wife doubtful of her husband's fidelity. Secondly Act 1 functions as small-scale model or gameplan for Acts 2 through 5.

The scene is the first of a series of two person exchanges which set up a network of relationships before the central 'lots' scene. The power relationship between the slaves changes-Chalinus is in control at first, but he is displaced almost immediately. The lines alone do not make sense of this change; one needs to consider what kind of staging will make sense of the lines. For example:

[Enter Olympio from stage left; paces angrily to centre stage, muttering behind him to Chalinus, who is hot on his heels.]

OL. Non mihi licere meam rem me solum, ut volo, loqui atque cogitare sine ted arbitro? 
Can't I talk and think over my own business, alone, without you spying on me?

[Olympio turns to confront Chalinus, who fails to stop. They collide. Olympio grasps Chalinus by the tunic and shouts.]

OL. quid tu, malum, me sequere?

Damn it, why are you following me?

[Chalinus extracts himself; brushes himself down; his tone when he speaks is self-consciously smooth and clear.]

$\mathrm{CH}$. quia certum est

quasi umbra, quoquo tu ibis, te semper sequi.

Because I've decided to follow you always, wherever you go, like your shadow.

[Olympio gives Chalinus another shove and makes to exit stage right. Chalinus, who is still attending to his personal appearance, does not follow immediately, except vocally. His next sentence is thrown triumphantly after Olympio.]

$\mathrm{CH}$. quin edepol etiam si in crucem vis pergere, sequi decretumst.

By god even if you choose crucifixion, I'm determined to follow.

[Olympio pauses, considering the image of Chalinus on the cross. He shakes his head, dismissing it as impracticable. Meanwhile Chalinus, aware that he has lost Olympio's attention, becomes more aggressive and overtly insecure.]

$\mathrm{CH}$.

dehinc conicito ceterum,

possisne necne clam me sutelis tuis

praeripere Casinam uxorem, proinde ut postulas.

So think it over, whether or not you can forestall me with your tricks by making Casina your wife, without my knowledge, just as it suits you.

[Olympio pauses, arrives at a decision, and strolls back to centre stage with an air of menace. His next line is equally cool and challenging.]

OL. quid tibi negotist mecum?

Do you have some kind of business with me?

[Chalinus takes a half-step backwards, obviously flustered-his next line is a resort to insults in an attempt to reassert control over the situation.] 


\section{BRONWYN WILLIAMS}

CH. quid ais, impudens?

quid in urbe reptas, vilice haud magni preti?

What's that you say, you impudent creature? Why are you creeping about the city, you worthless bailiff?

[Olympio is unperturbed.]

OL. lubet.

I like it.

The rationale for the above staging is this. While Chalinus stays physically close to Olympio, niggling him, the latter is irritated out of his usual self-possession. Olympio remains loud and angry, and it is easy for Chalinus to deal with him by remaining cool and quiet. Basic psychology tells that, unless you are in a position to offer violence, lost temper and 'noisy' anger waste energy and diminish control. Chalinus is able to play the role of sophisticated town-slave to Olympio's country-bumpkin. Chalinus, however, makes several mistakes. The crucifixion image, a deliberate extremism aimed at pressing a point, places him at a disadvantage, because it is a fiction which appeals to Olympio (who spends the second half of this scene devising other scenarios equally distasteful to Chalinus, but without negative consequences for himself). Chalinus provides Olympio with physical and mental breathing space, during which he calms down, and finds a more effective method of dealing with the situation. Moreover Chalinus, recognising something of his error, allows himself to become flustered and angry. Olympio has adopted a pose of collected aggression (with all the force of his hostility hitting its object). Olympio is advancing; Chalinus retreating. The power situation is reversed.

Of course these directions are not definitive; however they do constitute one of a small number of possible ways to stage the scene so as to make sense of the lines, complementing and elucidating the tonal changes of Olympio and Chalinus between and within speeches. ${ }^{14}$ Physically distancing Olympio from Chalinus complements the distancing effect of the crucifixion line-and gives Olympio room to move, in fact to advance on Chalinus. The visual switch in the advance and retreat modes parallels the verbal switch (and reinforces the military imagery of the prologue). If Olympio walks and talks simultaneously through his entrance, the audience will be aware that he is flustered; when he moves deliberately and deliberatively back to Chalinus, they will realise that he is about to take control. Chalinus' disarray will convince and be comprehended.

Olympio controls the remainder of the scene. When Chalinus tries again the role of town slave, relegating the country slave 'to [his] own province' (in praefectura tua, 99), Olympio counters self-importantly with the role of overseer, who.is in a position to delegate authority (105) and is therefore 
hardly a slave at all. (He refers to Casina as Chalinus' fellow-slave [conservam tuam, 108].) He is the superior talker: Chalinus has to resort to conventional insults and exclamations ('you-dug from the dung heap!' [ex sterculino effosse, 114]); Olympio's threats are originals. His victories over Chalinus are triumphs of the un- or anti-conventional over the conventional, the original over the copy or translation. His vivid depiction of an imaginary future (117ff.) silences Chalinus almost completely. (Chalinus' scornful 'what will you do to me?' [quid tu mihi facies?, 117] is repeated more seriously after the first part of Olympio's scenario, in the briefer 'what will you do?' [quid facies?, 132].)

Olympio conjures a fictive world, that is to say a play, in which Chalinus is a character and of which he is the audience. It is possible to stage the scene in such a way as to emphasise its metatheatricality, by what amounts to an on-the-spot rehearsal. As Olympio images jug, path, spring, pail and vats he loads Chalinus up with various imaginary properties, and points out fictional sets. Chalinus responds as if they were real, bending over, panting, breaking under the weight. He imagines that he tastes the dust and dirt, and experiences hunger and exhaustion-by the time he asks for the second time 'what will you do?', he merely looks up pathetically from the ground, with an air of being too weary to care any more. ${ }^{15}$ But when Olympio images him at the window, forced to observe his rival's success and love-play, he rises up, grasping at an imaginary window in jealousy and anger. He tries to break through the window, but is unable to do so, bound equally by his status as character in Olympio's play, subject to the constraints of Olympio's plot, and as captive audience to a piece of 'window' theatre (literally), which by definition precludes audience interaction.

Olympio, meanwhile, seems to become absorbed in his own fantasy, with an excessively long list of pet names to be uttered by his lady. Possibly one could bring the list to an end by having Chalinus make an agonised leap through his hypothetical window, into-the real world (or rather, his real world, which to the audience is still the world of the play). The noise startles Olympio and breaks the mood for both. Olympio turns and abuses Chalinus, who is still in a daze; exits, leaving Chalinus to recover himself and give chase. Chalinus' final line takes us back to where the scene began (except that now it is Chalinus who talks and runs all at once); for Chalinus it is a line which breaks through the barrier of Olympio's play and lands him back in a world in which, through Cleostrata's support, he wields some power. From the point of view of the campaign, first blood goes to Olympio's side.

Second blood goes to Cleostrata. In Act 1 strategic role-play and powerplay lead to theatrical play; Olympio absorbs Chalinus into a fictive world the terms of which are controlled by Olympio. Acts 2-5 adopt this model, and readapt it to the semi-realistic relationship between Cleostrata and Lysidamus; depict the relationship as enforced role-play and the dissatis- 
faction of both protagonists with the roles awarded them; depict next the various fictive worlds which each contrives in an attempt to change roles or the terms of the drama. ${ }^{16}$

At the beginning of Act 2 Cleostrata is kicking against the social constraints of her role as wife. The conventions of this role are represented by Myrrhina, with her distaff (the modern equivalent would be knitting needles), her concern with financial and social security and her correspondingly practical 'let him have his affairs, let him do what he likes' (sine amet, sine quod lubet id faciat, 206f.) philosophy. ${ }^{17}$ At this time Cleostrata's power to do otherwise is limited: although she perceives her husband's interest in Casina, she has no cognisance of his specific intentions, when or how he intends to execute his designs; once Chalinus puts these at her disposal, she is in a position to launch a counter-attack. (Also she seems more motivated to do so following the discovery that Lysidamus has the gall to carry on his affair in the house of their next-door neighbours.) In Act 3 she begins to take affirmative action.

In the meantime she has some power to block Lysidamus, which power she exercises. (Significantly, her first word in the play [obsignate, 'seal up', 144] connotes restriction and contrasts with the boisterous opening speech of her husband [217ff.].) She locks the pantry and absconds with the key (144ff.): food and love are linked throughout the play, analogically-love as the spice of life, the ultimate condiment (219ff.) - and later equivalently-love replaces food for Lysidamus (tibi amor pro cibost, 802); so Cleostrata's action in refusing her husband food symbolises her wish to prevent his love-affair. She opposes the marriage of Casina to Olympio-interposing her role as mistress of the household (which makes the care of servants her business, 259-61), and also their joint role as the parents of Euthynicus, with a responsibility to support the wishes of their son (262f.). Repeatedly she makes an obstacle of his old age-his role as senex, Old Man, at e.g. 240:

senecta aetate unguentatus per vias, ignave, incedis?

At your age are you wandering the streets dolled up with perfume, you wretch?

and 259f.:

mirum ecastor te senecta aetate officium tuom non meminisse.

It's a wonder by god, that you at your age don't remember your duty.

(Of course the latter quotation, which points ostensibly to Lysidamus' 
interference in Cleostrata's household duties, is also a [thinly] veiled allusion to his duties as a husband, and his proposed affair with Casina.)

It may be that Lysidamus pursues Casina precisely to escape the role of Old Man-to convince himself that he is not yet 'past it'. Myrrhina's surprise at Cleostrata's unhappiness, her ignorance of the situation so complete that she is unable to grasp the purport of Cleostrata's hints until the latter makes herself explicit, suggest that Lysidamus is not a habitual philanderer. ${ }^{18}$ So does his incompetence in the role. (He exudes perfume, and panics when confronted-his delayed excuses prompt a sarcastic aside ['how quickly he invented that' (ut cito commentust, 241)] from Cleostrata. Then again he slips up more than once in conversation, saying 'me' when he ought to say 'him' [364ff.; cf. 672ff.].) More significantly, he certainly is not motivated by real love: he talks of Casina only as the object of his affections. His opening song is self-absorbed, concerned with the change wrought by love to make a charming sophisticate of a once surly man (hominem ex tristi lepidum et lenem, 223), an assertion of his own lasting capacity to 'please' a beautiful young woman (227).

When Chalinus substitutes for Casina, Lysidamus does not notice the difference. He pronounces himself 'a free man' (liber, 836), praises Venus, and praises the bride's cloud-like breast (847). He attributes the violent rejection of Olympio to that suitor's roughness (850); when he himself comes in for a serve from Chalinus' elbow, he first screams with pain (vah, 851), but as soon as Olympio enquires 'what's up?' (quid negotist?) quickly moderates his response to 'my, what a strong little thing she is!' (opsecro, ut valentulast). ${ }^{19}$ Lysidamus sees what he wants to see. This is because Casina is not real for him, except as a symbol of eternal youth. ${ }^{20}$ Lysidamus is trying desperately to resume the role of adulescens amans, Young Man in Love--or of Jupiter (cf. 230 and elsewhere), eternally potent. If he fails he will be, in his own estimation, 'a useless old man' (nullum senem, 305). ${ }^{21}$

However, in trying to play a role for which he is no longer fitted he succeeds only in losing his grip on another role associated necessarily with his age-that is to say, his role as Master. He resorts to reasoning with Chalinus, and to conspiring with Olympio. Chalinus enters just as Lysidamus is uttering a prayer for his annihilation; his first word, te ('you') proffers an alternate object of perdant, 'may they destroy', and thus seems to turn the prayer back on Lysidamus (279f.):

LY. qui illum, di omnes deaeque perdant-

$\mathrm{CH}$.

te-uxor aiebat tua

me vocare.

LY. So him, may all the gods and goddesses destroy-

$\mathrm{CH}$. You [pause as Lysidamus jumps] were calling for me, your wife said. 
Lysidamus' response is an attempt to reassert his authoritative role in the household (280):

ego enim vocari iussi.

Well I commanded that you be called for.

It fails. Chalinus is off-hand or insolent to Lysidamus throughout the scene: 'say what you want' (eloquere quid velis, 280); 'suits me' (satis placet, 296); 'you hate the sight of me, but I'll live' (invitus me vides: vivam tamen, 302). He outstrips Lysidamus in debate (as when, offered a choice between freedom and marriage, he restates the options as marriage and wealth on the one hand, poverty and bachelordom on the other). Lysidamus' insults he meets with maddeningly (to Lysidamus) cool confidence (cf. 299ff.). All in all he adopts against his master-successfully-the approach used against himself earlier by his fellow-slave. (Compare for example lines 111-16). Lysidamus is powerless to prevent it, hamstrung by the need to strike a bargain with Chalinus. His preliminary gestures towards a reprimand change mid-speech to praise as he realises this (281ff.):

primum ego te porrectiore fronte volo mecum loqui;

stultitia est ei te esse tristem cuius potestas plus potest.

Firstly I'd like you to wipe that frown off your face when you speak to me; it's stupid of you to be surly with one more powerful than yourself. ${ }^{22}$

\section{[Hesitates.]}

probum et frugi hominem te iam pridem esse arbitror.

For some time now I've thought you an honest, deserving man.

No less apparent to the audience than Lysidamus' present inability to direct Chalinus' behaviour is his future inability to control the actions of Olympio, the implications of whose assurance-'Well, I said I wouldn't give her up for Jove himself, if he were to beg me' (negavi enim ipsi me concessurum Iovi,/ si is mecum oraret, 323f.) - are clear to all but Lysidamus. To him Olympio represents the salvation of himself and his hopes (312) - a role performed by Olympio with the appearance of casual boredom ('she begs, she entreats that I not take Casina as wife' [orat, obsecrat,' ne Casinam uxorem ducam, 321f.]) and boast ('Well, I said ... '). Whether Olympio was as much in command of the interview as his version of it 
suggests is questionable. It is tempting to consider it as another of Olympio's fictions, this one a partial rewriting of the event better to accord with the way Olympio wishes things had transpired. His re-entrance is important dramaturgically for this reason. He should be carried outside amid a great many shouts and wails, and dumped in the middle of the street. (Lysidamus' next line, 'But look, just in time, here comes Olympio' [sed progreditur optume eccum Olympio, 308], is humorously self-evidential, and a toying with the ancient dramatic convention of signalling entrances.) Next, catching sight of Lysidamus, Olympio jumps up, turns about and assumes an aggressive pose before the now closed door-whether the argument he conducts with the door is real or artificial the audience is left to doubt. (That Lysidamus doubts it not at all adds to the impression of his naivete concerning Olympio's motives.)

Lysidamus himself has begun to aggrandise and theatricalise his situation. He sees his recourse to the lots in epic terms as the dodging of a javelin (297); while in the event of ultimate defeat he imagines himself falling on his sword in true tragic mode ( $307 \mathrm{f}$.). In the course of conversation with Olympio, his discourse becomes increasingly militaristic (343f., $352,357)$, in the endeavour to give his love-affair the status of a great campaign.

The analogy has obvious sexual implications-Lysidamus is determined to prove that he can still wield a sword. However, he is soon to be emasculated: late in Act 3, Pardalisca has him running scared over the sword which, she claims, Casina intends to use against Lysidamus on their wedding night. In the event, he is confronted by the phallus/sword of 'Casinus'. Even his suicide plot connotes a masturbatory form of tragic climax, in which Lysidamus is forced to fall on his own sword. Lysidamus' Jupiter image takes an immediate battering on several fronts, not the least in Olympio's rather tactless reflection that mortal Jupiters have been known to die (333ff.).

For the audience the recurrence of the campaign motif from the prologue signals an end to preliminary skirmishes and the onset of the first fullscale battle. The ranks are assembled for the drawing of the lots: Cleostrata and Chalinus versus Lysidamus and Olympio. The scene which ensues functions on two levels. Chalinus and Olympio provide the slapstick comedy, exchanging insults in a manner analogous to that of their first encounter. (See, for example, lines 389-393.) Lysidamus and Cleostrata engage in a piece of social role-play, the 'civilised' couple: Lysidamus attempts to appear casual (de istac Casina, 'concerning this girl Casina', 372) and disinterested (optumum atque aequissumum istud esse iure iudico, 'I judge rightly that this is best and fairest', 375) - and when he slips up, Cleostrata pretends not to understand (365ff.). Husband and wife exercise their mutual antagonism tacitly and vicariously, through the open competition of their slaves. ${ }^{23}$ When Lysidamus instructs Olympio to 'smash that loathsome creature's mouth' (percide os tu illi odio, 404), it should be 
clear to the audience that it is Cleostrata really whom he would like to see struck. He might even point at her initially, then think the better of it and satisfy himself with her substitute. Cleostrata takes his meaning, and reciprocates (feri malam, ut ille, rursum ['hit him back-on the jaw, same as he did', 407]). Again, when Cleostrata says, 'you're beaten, Chalinus' (victus es, Chaline, 417), she is acknowledging her own defeat in the marital stakes.

The next scene results in a reversal of this defeat. Alone on stage Chalinus contemplates suicide, rejecting it as effort wasted (meam operam luserim, 424) —or made into a play. His refusal to self-theatricalise encompasses only the death of a tragic hero; two lines later he embraces a Sophoclean reluctance to give his enemies cause for pleasure (426). Lysidamus and Olympio enter, and Chalinus resolves to play the crab (imitabor nepam, 443) in order to overhear their conversation. The remainder of the scene is divided in two according to Chalinus' confusion or enlightenment concerning what transpires. At first he is in the position of an audience member unfamiliar with the plot, and who has arrived half-way through the play. Accordingly he misinterprets his enemies' discourse until Lysidamus' mention of Casina sets him straight. His asides to the audience concerning Lysidamus' previous advances towards himself should be understood in terms of his earlier grievance, that his master supported his rival so strongly (429ff.) - they amount to assertions of his (Chalinus') desirability, equal to that of Olympio. Like Olympio's earlier retelling of his conversation with Cleostrata (309ff.) they depict a scenario which may or may not have taken place, and will work better dramatically the more incongruous they seem in relation to the actions of Lysidamus and Olympio-who should thus play the scene for obvious pantomime and playacting, a parodic love scene (Olympio becoming nervous when Lysidamus gets too involved in the role).

During the latter part of the scene (468ff.) Chalinus is a more knowing, critical audience: his asides parody rather than puzzle over his rivals' discourse. He listens as Lysidamus expounds his future strategy. This also takes theatrical form-he plans to make Alcesimus' house 'the country' (id rus hic erit, 485). Lysidamus' appeals to Olympio to compliment the cleverness of his plot (satin astu?, 488) draw a sarcastic 'brilliant' (docte) from that slave, who is looking for excuses to spend the first night with Casina himself; while Chalinus remarks aside triumphantly, 'plot away' (fabricamini). Following the exit of Lysidamus and Olympio, Chalinus' military and tragic self-imaging are revisited and reversed: he anticipates the suffering of his enemies under his mistress's counter-strategies; recently conquered (victus, 428), the conquered have become the conquerors (iam victi vicimus, 510). At the end of the preceding scene Cleostrata was submitting perforce to the role of submissive wife, assenting without argument to the wishes of her husband (419ff.). She had nowhere else to go. When next she enters, all that has changed. Informed of Lysi- 
damus' specific plot, she is in a position to interfere with his play. She does so with a series of plays of her own, and the metatheatrical content of the play at large escalates.

\section{Everybody's An Actor.}

Lysidamus is an elderly auditionee for the role of adulescens amans, or Young Man in Love, for which Euthynicus' absence has left an opening. His conversation with Alcesimus at the beginning of Act 3 may be read metatheatrically as a discussion of his suitability for the part. ${ }^{24}$ Several of the chastisements which he enjoins Alcesimus not to employ- 'why the lover?' (cur amem, 517), 'with your grey hair!' (cano capite, 518), 'your age is against you' (aetate aliena, 518)-are appropriate not only to the old man indulging himself in an illicit affair, but also to the aging actor still in contention for young roles. ${ }^{25}$ Alcesimus' response, 'I've seen noone more wretched with love than you' (miseriorem ego ex amore quam te vidi neminem, 520), is a form of encouragement- 'you're perfect for the part!'. His groaned response to Lysidamus' pun on vocent ('vocal'/ 'vacant', 527) at 528-

attatae! caedundus tu homo es; nimias delicias facis

Oh no! You're a man needs cutting back; you're making too many jokes

-also functions as performance criticism: 'you're overacting'; 'you need to tone it down'. Equally Lysidamus' rejoinder ('what's the point of my being in love, if I'm not clever and witty?' [quid me amare refert, nisi sim doctus ac dicaculus?, 529]) defends his own performance in terms of his interpretation of what is required by the role. Lysidamus is concerned, too, to establish the part to be played by Alcesimus-whether he will depict a character supportive or hostile to his neighbour (amici anne inimici sis imago, 515).

In soliloquy Lysidamus plays the Young Lover self-consciously. His opening number in Act 2 (217ff.) is the first of several discourses upon the effects of love, performed for the benefit of the audience from the perspective of a Lover. It is a 'big' comic entrance, verbally excessive and topically ridiculous. Lysidamus' intention is to appear 'charming and sophisticated' (lepidum et lenem, 223; cf. doctus ac dicaculus, 529). ('Needs cutting back', Alcesimus might say.) In Act 3 Lysidamus again takes the opportunity to soliloquise (563ff.). Both in the earlier song, and now in this speech, he begins with a general philosophy of love, which he next applies to self: hanc ego de me coniecturam domi facio ('I make this conjecture from my own experience at home', 224); sicut ego feci ('I did 


\section{BRONWYN WILLIAMS}

exactly that', 566). In each case he is trying to demonstrate his fittedness for the part of Lover. In the latter instance it is the part of the Young Lover, carefree and irresponsible, grumbling at the petitions of his relative, and delighted at having lost the case.

His willingness to change roles with Olympio is another consequence of Lysidamus' desire to play the adulescens amans (734-38):26

LY. mane.

OL. quid est? quis hic est homo?

LY. erus sum.

OL. quis erus?

LY. cuius tu servo's.

OL. servos ego?

LY. ac meus.

OL. non sum ego liber?

memento, memento.

LY. mane atque asta.

OL. omitte.

LY. servos sum tuos.

LY. Wait.

OL. What is it? Who is this man?

LY. I'm the master.

OL. What master?

LY. Whose slave you are.

OL. Am I a slave?

LY. And mine.

OL. Am I not free? Remember, remember.

LY. Hold on a minute.

OL. Forget it.

LY. I'm your slave.

What Lysidamus 'remembers' is that a Young Man in Love needs a Clever Slave, to whom he can become subservient. (Compare Calidorus in Pseudolus, or Pleusicles in Miles Gloriosus.) Olympio hardly fits the specifications $^{27}$ - Lysidamus has had to do his own plotting, and it is Olympio's intention to keep Casina for himself-but he is the best Lysidamus can do, to satisfy theatrical convention. Nevertheless the judgment of the play is against him. He is referred to by others consistently as senex, Old Man. Lysidamus makes an ending similar to that of the soldier in Miles Gloriosus (both are stripped of their belongings, and threatened with a beating). The implicit verdict of the play is, 'You're too old to play the Young Lover, but we do have an opening for a Braggart Warrior.'

Lysidamus fails to convince as adulescens amans. His attempts at playwriting fail also, because not all of the actors will say the lines given them. 
His plot hinges first of all on emptying Alcesimus' house of its usual inhabitants. He has arranged it that Cleostrata will send for Myrrhina, and that Alcesimus will answer for his wife's attendance. When Cleostrata enters, Myrrhina is costumed (ornata, 540) and waiting backstage (that is, at home [domi] - which is part of the backstage area literally). Alcesimus is ready with his line and her cue ('do you want me to call her?' [vin vocem?, 544]). Her polite refusal places him in a predicament familiar to any actor who has ever been delivered the wrong line, or the right line at the wrong moment, in the course of an actual performance. Perforce he ad-libs ('she's got time' [otium est, 544]) and feeds her with leading lines ('aren't you organising a wedding over there among yourselves?' [non ornatis isti apud vos nuptias?, 546], 'so don't you need an assistant?' [non ergo opus est adiutrice?, 547]) in an attempt to get the scene back on course. Of course he does so to no avail, when Cleostrata is out to sabotage the play. It is not uncommon, when a play is in rehearsal, to make joking threats about altering critical lines in the presence of an audience. The question takes the form 'what would you do if I ... ?'. (What does Phaedra do, if Hippolytus says 'I feel the same way about you, darling'?) Cleostrata enacts the threat, and Alcesimus is left, appropriately, to ask the audience 'what do I do now?' (quid ego nunc faciam?, 549).

Cleostrata deceives first Alcesimus, and next Lysidamus, with a semirealistic performance: 'Cleostrata as herself'. Alcesimus is turned from the notion that Cleostrata has found them out when he reasons that, if that were the case, she would have been more openly aggressive (554-56). It does not occur to him that she is 'playing' ignorance, with the aim of vengeance. Lysidamus is readily taken in by her abuse of 'that mate of yours, your best friend' (hic sodalis tuos, amicus optumus, 581). She is setting them up (ludificatus, 558; ludificem, delusi, 560)-playing tricks on them-and tricking them into a play. ${ }^{28}$ When next they encounter one another, Lysidamus and Alcesimus are no longer actors in control of their parts, but puppet-characters in a farce devised by Cleostrata. ${ }^{29}$ The scene beginning at line 591 is a comedy of joint confusion and mutual exasperation, in which each fails to realise that both have been duped. Lysidamus prefers to see it as tragedy, himself the heroic victim of divine displeasure (616ff.). So he makes a credulous audience for Cleostrata's next production: 'Scene from a Greek Tragedy', performed by Pardalisca.

Sound effects from the house attract Lysidamus' attention, and his alarmed inquiry provides an obvious cue for Pardalisca's entrance. ${ }^{30}$ The scene between them can be divided into several parts. Lines 621-30 are window theatre. Pardalisca is the actress and Lysidamus the uncomprehending audience. She occupies the stage with a melodramatised tragic 'soliloquy', the exaggerated language of which demands a 'big' performance. She appears no more aware of Lysidamus than of the 'real' audience. He aligns himself with the audience when he appeals to it for an explanation of her behaviour (630). A moment later he alters his approach by 


\section{BRONWYN WILLIAMS}

addressing her directly (631). Momentarily she ignores him, as she continues to proclaim herself 'ruined' (perii); next, admits to having heard something; finally (after additional prompting from Lysidamus), acknowledges the presence of her master. What has taken place is a change in the nature of the drama. Lysidamus has broken the window, and passed through it into the world of the play. His 'just look at me' (respice modo ad me, 632) constitutes a demand to be included, taken into account, and not passed over as if he did not exist.

However, Pardalisca's manner of noticing him-'whence came that sound to my ears?' (unde meae usurpant aures sonitum?, 631)-keeps the play in the pseudo-tragic mode. Her mode of address ('o master mine' [ $o$ ere $m i, 632]$ - here and a few lines later being the only occasions upon which Lysidamus is recognised as 'master') signals that she is just finding him a role in Cleostrata's mini-drama, without altering any of the essentials of her plot structure. During this sequence (631-647) Lysidamus tries without success to uncover Pardalisca's 'news'. Meanwhile he is being blocked into the play $(634-41)$ :

PA.

ne cadam, amabo, tene me.

So I don't fall, hold me, please.

[With this Pardalisca stages a half-faint into the arms of Lysidamus. He is amazed, but catches her awkwardly. His next line reveals his alarm.]

LY. quicquid est, eloquere mi cito.

Whatever it is, tell me quickly.

[Pardalisca ignores this, and instead goes about repositioning them both, and directing him.]

PA. contine pectus.

face ventum, amabo, pallio.

Hold my waist. Make a breeze with your cloak, please.

[She demonstrates. Lysidamus does as he is told, and throughout his next line-spoken out to the audiencecontinues fanning her.]

LY. timeo hoc negoti quid siet;

nisi haec meraclo se uspiam percussit flore Liberi.

I'm afraid there must be some kind of trouble; unless perhaps she's knocked herself out somewhere drinking unmixed the flower of Bacchus.

[Pardalisca draws his attention back to herself.]

PA. optine auris, amabo. 


\section{GAMES PEOPLE PLAY}

Take hold of my ears, please. [Lysidamus gives her one astonished stare before shoving her away from him in angry frustration.]

Lysidamus is like a stand-in actor being taken through his marks: 'at this point you have to catch me'-'no, not like that-like this'-'now revive me' (and so on). Moreover he is a stand-in who has been misled as to the nature of his role: he had been led to believe that he was playing the hero, 'the master'; instead he finds himself the buffoon. When the directions he receives become unambiguous in this respect, he walks out of the play, not without considerable abuse of his director and fellow-actor (cf. 641ff.). Pardalisca tries to save the situation by addressing him once again as 'master mine'. When that fails, she bursts into tears, 'you're terribly unkind' (nimium saevis, 646-7), so adopting the role of weak female to Lysidamus' rough male; he, being the stereotypical male unable to cope when a woman cries, having vented his frustration in a muttered 'you speak too soon' (numero dicis), alters his tone and appeals again for information.

During the next part of the scene (up to about 682f.) Lysidamus hears gradually about the 'off-stage action' and attempts to grasp its significance. Pardalisca obstructs his progress first by a pose of hesitancy and disconnected thoughts, so that the story comes out with tantalising slowness (key words like 'life' [vitam, 658] and 'sword' [gladium, 660] being introduced and then left hanging deliberately). Secondly she keeps changing the tone of her own performance, in a way which makes it difficult for Lysidamus to know how to respond. For example, she breaks off in the middle of describing Casina's threats (in a tone of shock) to interrogate Lysidamus (in a surprised, matter-of-fact tone): 'does this pertain to you somehow?' (an quippiam ad te attinet?, 672); 'what business have you with her?' (quid cum ea negoti tibist?, 673). But when Lysidamus asks 'so she's not threatening me at all?' (num quid mihi minatur?, 676), she replies-in a tone of concerned surprise - 'to you alone she is hostile, more than to anyone else' (tibi infesta solist /plus quam cuiquam, 676f.).

At other times she pauses mid-performance to spell out some aspect of the plot, surprised apparently and not a little irritated by Lysidamus' naiveté concerning the conventions of the genre within which they are operating. Take for example lines $660 f$.:

PA. gladium-

LY. hem?

PA. gladium-

LY. $\quad$ quid eum gladium?

PA. habet.

PA. The sword-

LY. Huh? 


\section{BRONWYN WILLIAMS}

PA. The sword-

LY. What's this about a sword?

PA. She has one.

Pardalisca's first 'the sword' is uttered tragically, in performance mode. At Lysidamus' interjection she repeats herself-but prosaically, more like a fellow audience member supplying a line missed by her companion. When Lysidamus persists in his confusion ('what's this about a sword?'), she interprets impatiently: 'she has one'. Implicit is 'what do you expectthis is a tragedy, isn't it?'. Accordingly she chooses to disregard Lysidamus' next question, the obvious 'why does she have it?' (cur eum habet?, 661); just stops and stares, perhaps, before continuing the narrative in her own way. A little further on she is interrupted once again. Lysidamus' 'what kind of evil has been cast upon her so suddenly?' (quid illi obiectumst mali tam repente?, 666) is phrased appropriately enough for its 'tragic' context, but is itself inappropriate (inasmuch as it ought to be unnecessary). Pardalisca's explanation ('she's mad!' [insanit!, 667]) should be uttered in such a way as to indicate that she thinks him particularly obtuse.

So far, then, the scene has passed through several phases metatheatrically: the window theatre sequence, in which Pardalisca was actress and Lysidamus audience; the rehearsal sequence, with Pardalisca as actor/director and Lysidamus as unwilling stand-in actor; the critical analysis sequence, in which Pardalisca is the knowing 'reader' of dramatic productions and Lysidamus the novice. Next follows acknowledgement of the real audience by both (a 'chat with the cast' sequence?). Lysidamus admits to the role of Elderly Lover (senex ... amator, 684) - the most wretched Elderly Lover of all time. Pardalisca alerts the audience to the fact that her character has been playing a trick on his (ludo, 685; ludere, 688); carrying out a scheme or plot (dolum, 687) produced (protulerunt) by Cleostrata and Myrrhina; that is, acting out a part in a play within the play.

The remainder of the scene is different. It is concerned with Lysidamus' attempts to enlist Pardalisca's help, so that he can hide behind his wife's apron strings. (Lysidamus might want to compare his love affair to a military campaign, but real swords were more than he had in mind.) Pardalisca makes one or two impromptu embellishments to Cleostrata's plot (like the additional sword); while Lysidamus uses the tragic mode to explain his latest slip of the tongue. ('Fear hinders my words' [timor praepedit verba, 704] echoes-whether desperately or sarcastically_Pardalisca's earlier 'fear hinders the words on my tongue' [timor praepedit dicta linguae, 653].) Act 3 is completed by a scene featuring a stock character, in the shape of Citrio the Cook, on-stage; in the next act the cooks belong in Cleostrata's comedy. 


\section{The World of the Play}

Acts 4 and 5 are overtly metatheatrical. Act 4 begins with Pardalisca's assertion that the games being staged (ludi ludificabiles) inside the house, for the benefit of Lysidamus and Olympio, compare favourably with any games (ludos) ever held at Nemea or Olympia (759ff.). Act 5 opens with the entrance of Myrrhina, come to watch the wedding games (ludos ... nuptialis) out on the street (855f.). The scene described by Pardalisca in Act 4 is a farce: everyone rushing about-Lysidamus chasing the cooks about-Olympio strutting about - the cooks clowning about. Preparations are in progress too for the coming attractions. Olympio, clothed in white and sporting a crown, is costumed already for his role as bridegroom. Cleostrata and Myrrhina are occupied in fitting up (exornant, 769) Chalinus for the part of Casina. The multiplicity of activities, general rush and tear, high energy level of all, evoke a credible image of amateur theatrics.

Moreover, all who enter hereafter (during this act), enter 'in character'. First Lysidamus emerges from the house playing the faithful husband, off to the country as escort and protector to the newly-weds (780ff.). His performance is a little forced, with its emphasis and re-emphasis upon his chosen destination ('in the country' [ruri, 781]; 'to the country' [rus, 783]), and overstated in its pose of moral superiority-' 1 know the wicked ways of the world' (novi hominum mores maleficos, 783). Of course this 'I know the wicked ways of the world' is ironic in the context of Lysidamus' real intentions (of which his audience, Cleostrata, is fully aware). Specifically it points the distinction between the actor and the role he plays. (The modest Casina can be played by a whore [cf. $81 \mathrm{ff}$.]; here the young bride's chaperone is played by her prospective lover.) The whole performance is necessitated by the convention of explaining absences (cf. $64 \mathrm{ff}$.): Lysidamus is furnishing Cleostrata with a reason for his absence from the family's evening scene.

Outside and out of earshot, Lysidamus reverts to his preferred role, that of the lover. He is obstructed first by the presence of Pardalisca, and next interrupted by the arrival of Olympio. The scene will work best as two failed attempts to soliloquise. Lysidamus finishes talking back to Cleostrata, turns, adopts a different posture, and is about to launch into a private discourse with the audience, when out of the corner of his eye he spots Pardalisca. His 'what are you doing here?' (quid tu hic agis?, 789) is uttered with the annoyance of an actor interrupted in the middle of a big scene. Pardalisca exits, and Lysidamus tries again. He manages to deliver just one line before the sight of Olympio forces him to abandon the speech altogether.

Olympio himself is engaged in issuing directions to the flute player-a music rehearsal for the wedding scene. He and Lysidamus join in singing a wedding song, in an attempt to hurry the women on-stage (806); the music functions as the cue for their entrance. It appears to work-Parda- 
lisca enters with 'the bride' after only a moment's delay. However Pardalisca's parodic version of the wedding song, with its tradition-inverting injunctions to the new wife to outlive, dominate, waste and cheat her husband, signal that it belongs to Cleostrata's farce and not to Lysidamus' romance. Add to this a burly - and distinctly unpretty - 'Casinus' and the incongruous entreaty that Olympio 'go gently with this untainted and inexperienced girl' (integrae atque imperitae huic impercito, 831f.). Following the 'wedding', Lysidamus and Olympio begin to put their respective romantic schemes into action, only to find themselves characters in a play over which they have no control. At the end of Act 4 the audience is entertained with a slapstick routine written and produced by the play's women.

At the beginning of Act 5 the production team have come out front to watch the remainder of the performance. Their early conversation resembles that of an expectant audience, enthusiastic about the quality of the play and eager to see what happens next. Their aspirations differ: Pardalisca wants to know what the new bride has been doing with his new husband; whereas Cleostrata hopes to see the Old Man emerge the victim of a beating. Cleostrata's lines (862f.) -

optunso ore nunc pervelim progrediri

senem, quo senex nequior nullus vivit

I long to see the old man come out with his face beaten in-there's no old man alive more wicked than him

-involves a double entendre. On the one hand it functions analogously to Pardalisca's simple wish concerning the type of comedy with which they are about to be entertained. The senex referred to is the generic Old Man, and his alleged wickedness is something larger than life-unreal, exaggerated, theatrical. The line draws attention apparently to the unreality of the world of the play. However, Cleostrata and the audience know that there is one Old Man - alive-who is no less wicked than Lysidamusand that is Lysidamus. Real hostility motivates her longing for a violent conclusion. The serious tone of her speech contrasts with Pardalisca's frivolity. The audience is reminded that Cleostrata's 'play' constitutes her only means of response to a very real problem. Only in the context of the play (as writer/director) is she able to control the actions of her spouse. Appropriately her level of involvement in the drama is much greater than that of Myrrhina, whose different attitude and expectations concerning the marital state were voiced earlier (in Act 2). Myrrhina would never act as Cleostrata has acted, for all she might assist and applaud her friend's performance. Her role in life fundamentally is that of spectator. So in Act 5 she relaxes into the role of audience member, delighted by the play $(857 \mathrm{f}$., $860 f$.), and eager to pass remarks on the quality of the performances ('he's 
telling it very nicely', perlepide narrat, 927), or to speculate on the progress of the plot (' $I$ believe he lost it in adultery, when he was screwing Casina' [in adulterio, dum moechissat Casinam, credo perdidit, 976]).

Myrrhina is speaking when Olympio makes to enter; she is silenced by Cleostrata: tace; vostra foris crepuit ('be quiet; your door creaked', 873f.). The formulaic creaking door, like the dimming of the house lights in a modern theatre, signals that the performance is about to recommence, and that the 'audience' should stop talking, settle down and pay attention. The specificity of vostra foris ('your door') is such that the line also functions like a spotlight on the precise area of the stage from which the ensuing act(ion) will originate. Olympio's entrance reinforces the notion that the performance is just beginning; his injunction to the audience to give him their attention (operam date, 879), and his assurances that they will be suitably entertained for their pains (879f.), are in the manner of a prologue. ${ }^{31}$

This is Olympio's big moment. The eyes of the twin audiences (on-stage and off-stage) are upon him. Throughout Casina Olympio's perception of his role in the world has placed him centre stage. He has scripted scenes for himself: one in which he and Casina curl up together at his country residence, to his own delight and to the humiliation of his rival; another in which he defies his mistress in an open confrontation concerning his impending marriage. He plays the lover of Casina and the saviour of the hopes of Lysidamus with equal verve (if not with equal sincerity). $\mathrm{He}$ is the hero of his own play in each case. Moreover he seems oblivious to the fact that the focus of the world (or the play), within which Lysidamus and Cleostrata are acting, is elsewhere. Olympio entertains seriously the possibility that he, the slave, will win the girl. He is the method actor who, when asked about Casina, replies 'it's all about this slave ... '. And he is as every individual, for whom the centre of the universe is self.

However Olympio's 'real world' has fallen short of and proved less controllable than his fictional worlds. Olympio's opening soliloquy focuses on his unsuccessful attempts to realise his original fantasy of cosy lovemaking: the fantasy envisaged Casina whispering sweet nothings for the benefit of her beloved Olympio; the reality turned out to be the unpleasant reception by 'Casinus' of Olympio's advances. Nor is Olympio allowed to soliloquise at length; rather, he is interrupted by Pardalisca at the instigation of her mistress. According to pre-arrangement (Cleostrata's plot-outline) Pardalisca was to take a key role in this scene, ridiculing whoever emerged from Alcesimus' house (866ff.). Olympio enters in self-derisive mode, rendering Pardalisca's intervention dispensable in one respect. It is necessary, nevertheless - as Cleostrata's prompting of Pardalisca indicates. Otherwise Olympio, and not Cleostrata, is controlling the direction which the scene will take. Pardalisca reinstates Cleostrata as playwright and simultaneously reduces Olympio to the role of slow-witted slave (whose confusion of 'Casinus" phallus and Casina's sword farcically reworks the 
blatant sexual overtones of the military imagery employed by Lysidamus). ${ }^{32}$ Significantly Pardalisca makes a concluding reference to Olympio's loss of the 'little cloak' (palliolum, 934), which formed part of his 'bridegroom' costume. Olympio's aspirations to the role of bridegroom are finished.

Similarly Lysidamus' forfeit of cloak and staff $(945,975)$, which are part of the costume and properties of a respectable old man, signify the inappropriateness of his recent behaviour for one of his age and position, and call into question Lysidamus' future status as husband and as master. He himself does not know how to face his wife; his present costume (hoc ornatu, 974) is exactly that of one caught out in the middle of an illicit affair (clandestinae nuptiae, 946). Accordingly both Chalinus and Cleostrata accost him openly with the title of 'lover-boy' (amator, 960, 969)which of course also functions to locate him as Elderly Lover (senex amator) rather than Young Man in Love (adulescens amans); she again addresses him as 'bigamist' (dismarite, 974). Lysidamus enters into the role of slave anticipating, albeit unwillingly, a deserved punishment (although in this he is hopeful of finding a volunteer from the audience to substitute during the actual performance); but resolves instead to imitate the 'wicked slaves' (improbos famulos, 953) by absenting himself from home. ${ }^{33}$ Certainly the runaway slave provides a more appropriate role model for Lysidamus, whose principal object in the final stages of the play is to avoid any of the negative consequences which ought to follow naturally from his infidelity. He shies away from his wife's threats of prolonged confrontation, and his willingness to accept her version of events in its entirety wins him a complete and unconditional pardon (998ff.) and the restoration of his properties (1009).

Cleostrata advances a metatheatrical motive for her ready forgiveness of Lysidamus (1006):

... hanc ex longa longiorem ne faciamus fabulam.

... lest we make this long play longer.

The line has greater significance than its 'throw-away' style suggests. Lysidamus and Cleostrata have to operate in the real world. Cleostrata has won a victory in the world of the play only. She has created a fiction (fabula) in which Lysidamus is forced to perform a certain role. His promises of future fidelity are conventional, reminiscent of the promises elicited from the soldier at the end of Miles Gloriosus. They belong to the world of the play. In reality they signify little about the future of Lysidamus' marriage. Moreover, Cleostrata's willingness to reinstate Lysidamus as her husband, immediately and without negotiation, augurs badly for her. Her first entrance in Act 2 saw her rebelling against the conventions of her role as wife. Contrary to the expectations of Myrrhina, she has shown that she 


\section{GAMES PEOPLE PLAY}

is not constrained by these; it is not necessary for her to accept, tolerate or turn a blind eye towards her husband's indiscretions. Yet here in Act 5 she conforms to the image of the forgiving wife, hopeful that this will prove to have been an isolated aberration on the part of her husband. She has no real alternative, if she wants a husband and not a puppet-character. However there is a tension between the uncertainties associated with the semi-realistic happy resolution arrived at by Cleostrata and Lysidamus, and the certainty of the conventional happy ending for Euthynicus and Casina (two characters so unreal that they do not even appear on-stage in this play), as reiterated by the epilogue.

\section{What Do the Critics Say?}

Plautus' Casina is a play about the making of plays. Casina focuses on the constraints imposed upon theatrical personnel by things external to themselves-the extent to which writers, actors and directors can or cannot control the nature and quality of the finished dramatic product. The metatheatrical design of Casina has an additional purpose: to point up the functioning of human relationships as the attempt to write, act and direct the circumstances of one's life and of the lives of one's associates. The odds in favour of a flawless performance are limited. ${ }^{34}$

\section{University of Sydney}

\section{NOTES}

1. Its metatheatrical design is consistent and coherent. N.W. Slater, Plautus in Performance (Princeton 1985) draws attention to a number of metatheatrical elements in the play; R.C. Beacham, The Roman Theatre and its Audience (London 1991), to more. However, no critic yet has done justice to the systematic, thematically unifying deployment of metatheatrical strategies in Casina. W.E. Forehand, 'Plautus' Casina: An Explication', Arethusa 6 (1973) 233-56, has interpreted the play holistically, as an account of the consequences of Lysidamus' lechery, but is almost apologetic concerning his enthusiasm for Casina, which he considers 'bare' with respect to plot, and shallow with respect to characterisation and the treatment of philosophical issues (233). I shall attempt to argue that the serious social issues which underscore the play's comedy are developed thoroughly (morally, not moralistically) by means of the play's metatheatrical strategies.

2. Compare the party wall in Miles Gloriosus. The audience knows that the cast is able to come and go between the two 'houses', that is the backstage area, but for the purposes of the play accepts that they are separate structures. Palaestrio creates a party wall, by which Philocomasium may come and go, undetected by Sceledrus. He thus recreates the space as backstage area.

3. Contrary to Slater (n.1 above), who deems it an unnecessary supplement to the play's action (72). Forehand (n.1 above) recognises that 'the prologue's remarks may have also an organic relationship to the meaning of the play' (236), which includes the establishment of a non-illusory, self-consciously theatrical context, and the signalling of a plot which departs from the conventions of Roman Comedy both in substance and tone. 


\section{BRONWYN WILLIAMS}

4. However, the suggestion of F. Skutsch, 'Ein Prolog des Diphilos und eine Komödie des Plautus', Kleine Schriften (Berlin 1914), 184-96, that Fides utters the prologue, is unnecessary and unconvincing. My own inclination is that the speaker of the prologue is Cleostrata, inasmuch as she is Casina's principal playwright (apart from Plautus himself: see lines 34 and 65), and this play's answer to the servus callidus.

5. Cf. F. Leo, Plautinische Forschungen (Berlin 1912), 207 n.2. Slater (n.1 above) argues that most of the prologue is post-Plautine, drawing attention particularly to the several references to the author by name. Slater's reluctance to admit these references as Plautine, rather than post-Plautine, is surprising in the light of his sympathetic attitude towards a self-reflexive, metatheatrical reading of Plautine comedy.

6. Plautus' audience is sensitised to the pun on ludus. Miles Gloriosus, the principal (metatheatrical) concern of which is the delineation of the elements of theatrical production (script, direction, casting, costumes, etc.), manipulates the same word-play (cf. J.A. Hanson, 'The Play's the Thing', presented at Dartmouth College in 1982).

7. I am less interested in the actual content of Clerumenoe than in Plautus' version of the play. (Of course, these two things might be identical.) Plautus sets before the audience a conventional'Greek New Comic plot structure, against which to bounce his own, less conventional, Roman play.

8. Compare, for example, Cistellaria $120-48$.

9. Cf. Slater (n.1 above), 70: 'Its [Casina's] virtues are in part its very departure from, or omission of, standard Roman comedy plot elements.'

10. Also, if Casina did appear, 'she' would be played by a 'he'-exactly as Cleostrata arranges it. (Cf. Beacham [n.1 above], 90.)

11. Contrary to Forehand (n.1 above), who accepts the slave wedding sequence at face value, and as an assertion of 'the basic credibility of certain details' (236).

12. Cf. Plautus' Persa.

13. Contrary to Forehand (n.1 above), who considers that this scene leaves itself a bitter aftertaste (237). However, it does not follow from the fact that the characters of a comedy take themselves seriously that an audience will feel compelled to take them so, and the scene between Olympio and Chalinus has comic potential which ought to be exploited.

14. I was interested to note that Beacham (n.l above) also assumes that Olympio and Chalinus collide early in the scene, 'thus immediately giving their confrontation a physically violent expression' (91). However, I have chosen to make it a head-on collision with a view to Olympio's next line and action, whereas Beacham's Chalinus is still niggling Olympio from behind.

15. I prefer this to the staging intimated by Beacham (n.1 above), 'with Olympio manhandling Chalinus throughout the sequence, while perhaps miming the sort of torments awaiting him' (93). It allows the two characters to interact in a more interesting fashion, and also promotes the play's focus on fictional worlds-plays, authors, and audiences-to a much greater extent.

16. Unlike the authors of previous interpretations (Forehand [n.1 above]; Slater [n.1 above]; W.T. MacCary, 'The Bacchae in Plautus' Casina', Hermes 103 [1975], 459-63; J. Tatum, Plautus: The Darker Comedies [Baltimore 1983]), I place little emphasis on Lysidamus' 'lust'. (See below.) In fact these critics differ vastly in their attitude and response to Lysidamus: Forehand considers him 'thoroughly objectionable ... from beginning to end' (253); whereas Tatum argues that 'in laughing at Lysidamus we come to feel a wry affection for him' (88f.). Tatum's experience of actual performance rings true, although I would like to see Cleostrata played with a lighter touch than his comments seem to imply. Cleostrata should come over as a woman who loves her husband and wants to throttle him (otherwise neither her decision to risk her official status as Lysidamus' wife, in order to regain her personal status in that role, nor the 'happy ending' make any sense at all dramatically). Lysidamus must be sufficiently lovable that the audience does not find his reconciliation with his wife distasteful-and sufficiently dubious morally to make it doubtful of her future happiness.

17. I do not see the exchange between Cleostrata and Myrrhina turning 'progressively nastier' (cf. Beacham [n.1 above], 95).

18. Contrary to general critical opinion. And subject to qualification. But in the first place there is just sufficient ambiguity associated with Lysidamus' advances on Olympio, and alleged past advances on Chalinus, to make the audience uncertain about the status of these. In the second place Cleostrata seems not to feel threatened by anyone in the play apart from Casina. If in fact Lysidamus is prone to chasing the male slaves then she is either unaware of it or unconcerned about it. Possibly this is because only another woman can challenge her relation- 


\section{GAMES PEOPLE PLAY}

ship with Lysidamus. In that case his homosexual liaisons are irrelevant here.

19. I am assuming that lines 851-53 should be attributed as follows:

LY. at mihi, qui belle hanc tracto, non bellum facit ...

vae!

OL. quid negotist?

LY.

opsecro, ut valentulast ...

LY. But she does not make war on me, who handle her gently ... aah!

OL. What's up?

LY. I say, what a strong little thing she is ...

This makes sense dramatically, and is more easily reconciled with the presentation of Lysidamus and Olympio. In the preceding lines, Olympio responds more simply and suspiciously to the unexpectedly violent behaviour of his new 'wife'.

20. She is more real to Olympio, which is why he is more inclined to fear the aggressive mock wedding song of Pardalisca, and to suspect the activities of 'Casinus'.

21. In this case Casina is not concerned, as Slater (n.1 above) believes it to be, with 'lust so excessive and animalistic that it becomes sex without joy' (93); nor is Lysidamus a figure of sexual domination over his household, as MacCary (n.16 above, 462) considers him to be. Rather, he is like the husband and father in the film Moonstruck (MGM 1987) who, in the opinion of his wife, chases women 'because he fears death'.

22. Beacham (n.1 above, 97) notes well the metatheatrical joke here: 'Chalinus cannot change his expression because he wears a mask.'

23. Cf. E. Segal, Roman Laughter' (Oxford 1987), 24f.: 'The Casina presents a situation closest to an actual husband-wife fistfight, when old Lysidamus urges his slave to strike his wife's servant, while he stands toe-to-toe with Cleostrata, arguing violently ... husband and wife pummel each other by proxy.'

24. Both Slater ( $\mathrm{n} .1$ above, 84) and Beacham ( $\mathrm{n} .1$ above, $232 \mathrm{n} .26$ ) miss this second level of discourse when condemning Lysidamus for his refusal to accept the criticisms owing to an elderly lover.

25. Compare the prologue to Terence's Heauton Timorumenos, in which the leading player explains the playwright's decision to cast an old man in a part usually assigned to a young actor.

26. Contrary to Beacham (n.1 above), who sees it as 'a graphic demonstration ... of how Lysidamus has been brought low by his unseemly and brutalising lust' (108).

27. Cf. Slater (n.1 above), $86 \mathrm{f}$.

28. Cf. ibid. 85 n. 26 .

29. No longer the barking wife; rather, the barking playwright!

30. No doubt, some of Cleostrata's stage crew are peeking out, visible to the audience, but unnoticed by Lysidamus, in order to cue the initial sound effects and then Pardalisca's entrance.

31. Slater (n.1 above), $88 \mathrm{f}$.

32. Cf.Tatum (n.16 above), 88: 'The symbol of male dominance of the female brings about the complete overthrow of the male and becomes merely the phallus of comedy, an object of ridicule, not power.'

33. Slater (n.1 above) rightly regards this moment as the logical consequence of Lysidamus' self-degradation from the position of master to the situation of slave. Beacham (n.1 above) shows how even this role is denied Lysidamus, who is 'set to start, only to freeze at the "starter's block" when Chalinus' cry rings out from the porch of Alcesimus' house, "hold it right there, lover boy!"' (113f.).

34. Several friends and colleagues read and commented on an earlier draft of this article. Thanks David Konstan, Tony Boyle, Frances Muecke, Bill Dominik, John Penwill. 